\title{
SHOX2 gene methylation in Egyptians having lung cancer
}

\author{
Mohamed Mostafa Mohamed Ahmed Rizk', Suzan Mohamed Farouk Helal', Ahmed Youssef Shaaban Gad ${ }^{3}$, \\ Doreen Nazeih Assaad Younan ${ }^{1 *}$ id and Salma Abd El Maguid Mohamed Ramadan Moemen ${ }^{1}$
}

\begin{abstract}
Background: Lung cancer tumorigenesis is mainly due to accumulation of genetic and epigenetic events in the respiratory epithelium. Epigenetic alteration is more frequent than somatic mutation in lung cancer. CpG island methylation of homeobox-associated genes is commonly seen in most early stage tumors. This study aimed at examining the potential usefulness of DNA methylation biomarker SHOX2, in broncho-alveolar lavage, in the diagnosis of lung cancer. Broncho-alveolar lavage was obtained from 80 patients; 60 cases with lung masses (proved malignant by histopathology) and 20 age and gender matched patients with benign lung lesions (benign controls). SHOX2 methylation status was evaluated using methylation analysis by restriction endonuclease digestion and real-time PCR.

Results: SHOX2 methylation level ranged $3.90-77.16 \%$ in cases, and $3.52-7.86 \%$ in controls, ( $p \leq 0.001)$. SHOX2 methylation levels in comparison to tissue biopsy pathology (the gold standard test) had $76.92 \%$ sensitivity, $70 \%$ specificity, $87 \%$ positive predictive value, and $53.8 \%$ negative predictive value in diagnosing lung cancer. Different methylation levels were noted in different lung pathologies, $(p=0.003)$, with the highest methylation levels in squamous cell carcinoma followed by adenocarcinoma and anaplastic carcinoma then lastly carcinoma in situ.
\end{abstract}

Conclusions: SHOX2 methylation levels could differentiate different varieties of lung cancer from benign lung lesions.

Keywords: SHOX2, Lung cancer, Egyptians, Methylation

\section{Background}

For several decades, lung cancer has been the world's most common malignancy particularly among males $[1$, 2]. Many risk factors contribute to the pathogenesis of lung cancer, e.g., smoking as well as exposure to radon, asbestos, diesel, and ionizing radiation [3].

Lung cancer is classified according to its histo-pathology into two broad classes: non-small cell lung carcinoma (NSCLC), the most common type, and small cell lung carcinoma (SCLC), the second most common type. Along with these 2 main types of lung cancer, other rare types

\footnotetext{
* Correspondence: doreenyounan@hotmail.com

'Clinical Pathology Department, Faculty of Medicine, Alexandria University, Khartoom Square, Azarita, Alexandria, Egypt

Full list of author information is available at the end of the article
}

may occur including: carcinoid, adenoid cystic carcinomas, hamartomas, lymphomas, and sarcomas $[4,5]$.

Chest X-ray and computerized tomography (CT) are usually the first clue for diagnosing lung malignancy. They also play an important role in lung cancer staging. Bronchoscopy together with cytology and histological diagnosis provide optimal diagnosis $[6,7]$.

Tumor markers have a great importance in screening for early malignancy, helping in diagnosing different types of cancer, determining prognosis, following up patients after surgery, and monitoring therapeutic response. Carcinoembryonic antigen (CEA), squamous cell carcinoma antigen (SCCA), neuron-specific enolase (NSE), cytokeratin 19 fragment (CYFRA), and pro-gastrin-releasing peptide (proGRP) can all be used with varying accuracies [8].

\section{Springer Open}

(c) The Author(s). 2020 Open Access This article is licensed under a Creative Commons Attribution 4.0 International License, which permits use, sharing, adaptation, distribution and reproduction in any medium or format, as long as you give appropriate credit to the original author(s) and the source, provide a link to the Creative Commons licence, and indicate if changes were made. The images or other third party material in this article are included in the article's Creative Commons licence, unless indicated otherwise in a credit line to the material. If material is not included in the article's Creative Commons licence and your intended use is not permitted by statutory regulation or exceeds the permitted use, you will need to obtain permission directly from the copyright holder. To view a copy of this licence, visit http://creativecommons.org/licenses/by/4.0/. 
Lung cancer tumorigenesis is mainly due to accumulation of genetic and epigenetic events in the respiratory epithelium. Epigenetic alteration is more frequent than somatic mutation in lung cancer [9, 10]. Since promoter hypermethylation can start early in lung carcinogenesis, it may thus have an important role in its early detection [11].

Detection of some of these early changes could be achieved by minimally invasive sample collection techniques, where aberrant DNA methylation can be detected as is the case with: sputum, broncho-alveolar lavage (BAL), and saliva of patients with lung cancer [12].

Short Stature Homeobox 2 (SHOX2) is a member of the homeobox family of genes and is known as SHOX homologous gene on chromosome three (SHOT), OG12, and $O G 12 X[13,14]$. SHOX2 gene encodes an intranuclear transcription factor. SHOX2 CpG hypermethylation influences gene expression, which could affect the expression of multiple genes regulated by $S H O X 2$, therefore promoting cell carcinogenesis. Genomic gain on chromosome 3q, where SHOX2 is located, has been recognized as one of the most prevalent and significant alterations in lung cancer [15].

The objective of this study is to determine the potential usefulness of SHOX2 DNA methylation in BAL as a biomarker for diagnosing lung cancer, which could be used for gene-targeted therapy. We also aimed at comparing these levels with other diagnostic modalities, like histopathology to detect their diagnostic accuracy.

\section{Methods}

The study design was a prospective case-control study conducted on 80 BAL samples obtained from 80 adult patients admitted to the Respiratory Department, sixty of whom had a suspicious lung mass on chest CT, which was later confirmed to be malignant by BAL cytology and/or histopathology of lung biopsy obtained by different techniques, e.g., CT-guided biopsy, ultrasoundguided biopsy, trans-bronchial biopsy, or open biopsy. Patients had neither co-exiting malignancies, lung metastases, history of chemotherapy nor previous lung malignancy. Twenty patients with benign lung lesions (e.g., foreign body aspiration, tracheal web, etc.), matched for age and gender, served as a control group, all had underwent bronchoscopy and BAL but did not show any evidence of lung cancer by CT or cytology/histopathology. Detailed clinical history including smoking habits, drug use was documented and full clinical examination, routine laboratory, and radiological investigations (chest Xray or CT) were also performed. SHOX2 DNA methylation levels were detected using methylation analysis by restriction endonuclease digestion and real-time PCR.

The study was approved by Institutional Research Ethics Committee (\#616.07) and a written informed consent was obtained from all participants before enrolment in the study. Patients were all coded and detailed information was stored confidentially. This work has been carried out in accordance with the Code of Ethics of the World Medical Association (Declaration of Helsinki and its later amendments) for experiments involving humans.

\section{Specimen collection}

All enrolled patients underwent flexible bronchoscopic examination to visualize the airways, assess the presence of endo-bronchial lesion, surgical accessibility for resection, obtain BAL for cytological analysis, and obtain tissue biopsy for histopathological examination. Bronchoalveolar lavage (BAL) samples were collected during bronchoscopy by aspiration from the region of the suspicious lesion after injecting $10-20 \mathrm{ml}$ of isotonic saline solution. Cytology from BAL was done to confirm or exclude malignancy.

\section{DNA Extraction}

DNA extraction was performed from the BAL using QIAamp DNA blood mini kit 50 (QIAGEN, Germany, cat. \# 51104) and measurement of DNA quantity and purity was determined using Nanodrop 2000 spectrophotometer.

\section{Digestion by Methylation Sensitive Restriction Enzymes}

The DNA samples were subjected to restriction digestion by EpiTect Methyl II DNA Restriction Kit (Qiagen cat. \# 335452), which prepares genomic DNA samples for DNA methylation analysis using EpiTect Methyl II PCR Assay. The kit contains: restriction digestion buffer, enzyme A (methylation-sensitive) and enzyme B (methylation-dependent). Using the enzymes and buffer provided in the kit, 4 digests were performed in order to detect different methylated DNA fractions. The product of a mock digest (Mo) contains all of the input genomic DNA. The product of the methylation-sensitive (Ms) restriction enzyme mixture (enzyme A) digest contains methylated DNA sequences, while the product of the methylation-dependent $(\mathrm{Md})$ restriction enzyme mixture (enzyme B) digest contains unmethylated DNA sequences. The product of a double digest (Msd) measures the background and the success of both enzymatic digestions.

Equal amounts of a genomic DNA (125 ng) were added to 4 separate tubes into which buffer $(13 \mu \mathrm{l} /$ tube) and the appropriate restriction enzyme combinations $(0.5 \mu \mathrm{l} /$ tube $)$ were added. The mock digest (Mo) had no enzymes added, enzyme $\mathrm{A}$ was added to the methylation-sensitive restriction digest (Ms), enzyme $B$ was added to the methylation-dependent restriction digest (Md), and both enzyme mixtures were added to the double digest (Msd). All digests were incubated at $37^{\circ} \mathrm{C}$ for $6 \mathrm{~h}$ in a thermal 
cycler (Thermo Scientific Arkitik Thermocycler) and the enzymes were heat inactivated at $65^{\circ} \mathrm{C}$, for $20 \mathrm{~min}$.

\section{Quantification of SHOX2 gene methylation percentage by real-time PCR}

After DNA samples were digested by restriction enzymes, SHOX2 gene methylation status was assessed using EpiTect Methyl II PCR Assay. The EpiTect Methyl II PCR Assay (Cat \#/ID: 335452) was used to analyze the amount of DNA in each digest of each sample to determine the methylation status of $\mathrm{CpG}$ islands in SHOX2 gene. The kit included the following: (1) $\mathrm{RT}^{2}$ SYBR Green ROX qPCR Mastermix (Qiagen catalogue number 330520) and (2) EpiTect Methyk II qPCR primer Assay (Human SHOX2) (Qiagen catalogue number 335002).

The method employed by the EpiTect Methyl II PCR kit is based on the detection of the remaining input DNA after cleavage with a methylation-sensitive and/or a methylation-dependent restriction enzyme. These enzymes digest unmethylated and methylated DNA, respectively. Following digestion, the remaining DNA in each individual enzyme reaction was quantified by real-time PCR using primers that flank a promoter (gene) region of interest. The relative fractions of methylated and unmethylated DNA were subsequently determined by comparing the amount in each digest with that of a mock (no enzymes added) digest using a $\triangle \mathrm{CT}$ method.

Briefly, input genomic DNA is aliquoted into four equal portions and subjected to mock (no enzyme), methylation-sensitive (MSRE), methylation-dependent (MDRE), and double (MSRE and MDRE) restriction endonuclease digestion ( $5 \mu \mathrm{l}$ of each enzyme). After digestion, the enzyme digests $(5 \mu \mathrm{l} /$ tube $)$ were mixed directly with qPCR master mix $(12.5 \mu \mathrm{l} /$ tube $)$ and dispensed into a PCR tubes containing pre-aliquoted primer mixes $(1 \mu \mathrm{l} /$ tube). Real-time PCR (Stratagene MX 3000P) was carried out using specified cycling conditions, (Supplementary material).

The product of the mock (no enzyme) digestion represents the total amount of input DNA for real-time PCR detection. In the methylation-sensitive digestion (Ms) reaction, the MSRE will digest unmethylated and partially methylated DNA. The remaining hypermethylated DNA (DNA in which all CpG sites are methylated) was detected by real-time PCR. In the methylation-dependent digestion (Md) reaction, the MDRE preferentially digested methylated DNA. The remaining unmethylated DNA was detected by real-time PCR. In the double digestion (Msd) reaction, both enzymes were present, and all DNA molecules (both methylated and unmethylated) were digested. This reaction measures the background and the fraction of input DNA refractory to enzyme digestion.
EpiTect Methyl II PCR assays provide gene methylation status as percentage unmethylated (UM) and percentage methylated (M) fraction of input DNA. Unmethylated represents the fraction of input genomic DNA containing no methylated $\mathrm{CpG}$ sites in the amplified region of a gene. Methylated represents fraction of input genomic DNA containing two or more methylated $\mathrm{CpG}$ sites in the targeted region of a gene.

The raw $\Delta C T$ values were inserted into the data analysis spreadsheet- provided by Qiagen (www.sabiosciences.com/dna_methylation_data_analysis.php), which automatically calculated the relative amount of methylated and unmethylated DNA fractions.

\section{Statistical analysis of the data}

Data was fed into a computer and analyzed using IBM SPSS software package version 20.0. (Armonk, NY: IBM Corp). Qualitative data was described using absolute values and percent. The KolmogorovSmirnov test was used to test the normality of distribution. Quantitative data was described as range (minimum and maximum), mean, standard deviation and median. Significance of the obtained results was judged at the $5 \%$ level.

Receiver operating characteristic (ROC) curve was generated by plotting sensitivity (true positive) on Y-axis versus 1 -specificity (false positive) on $\mathrm{X}$-axis at different cut-off values. The area under the ROC curve (AUC) denotes the diagnostic performance of the test. Area more than $50 \%$ gives acceptable performance with respect to $100 \%$, as perfect accuracy [16].

\section{Results}

Patients and controls were matched for age and sex ( $p=$ $0.114, p=0.19$ respectively, Table 1 ), inclusion criterion. Smoking was significantly more prevalent among cases than controls $(p=0.023$, Table 2$)$. Table 3 presents the

Table 1 Comparison between controls and cases regarding their demographic data

\begin{tabular}{|c|c|c|c|c|c|c|}
\hline & \multicolumn{2}{|c|}{$\begin{array}{l}\text { Controls } \\
(\boldsymbol{n}=20)\end{array}$} & \multicolumn{2}{|c|}{$\begin{array}{l}\text { Cases } \\
(\boldsymbol{n}=60)\end{array}$} & \multirow[t]{2}{*}{$\begin{array}{l}\text { Test of } \\
\text { sig. }\end{array}$} & \multirow[t]{2}{*}{$p$} \\
\hline & $n$ & $\%$ & $n$ & $\%$ & & \\
\hline \multicolumn{7}{|l|}{ Sex } \\
\hline Male & 12 & 60.0 & 50 & 83.3 & $x^{2}=2.342$ & ${ }^{\mathrm{FE}} p=0.190$ \\
\hline Female & 8 & 40.0 & 10 & 16.7 & & \\
\hline \multicolumn{7}{|l|}{ Age (years) } \\
\hline Min. - Max. & \multicolumn{2}{|c|}{$28.0-72.0$} & \multicolumn{2}{|c|}{$34.0-82.0$} & $t=1.688$ & 0.114 \\
\hline Mean \pm SD. & \multicolumn{2}{|c|}{$53.20 \pm 12.47$} & \multicolumn{2}{|c|}{$60.67 \pm 10.96$} & & \\
\hline Median & \multicolumn{2}{|c|}{54.0} & \multicolumn{2}{|c|}{60.50} & & \\
\hline
\end{tabular}

$\mathrm{X}^{2}$ : Chi square test, FE: Fisher exact, $t$ : Student $t$ test, $p: p$ value for comparing between the two groups

*Statistically significant at $p \leq 0.05$ 
Table 2 Comparison between controls and cases regarding their smoking status

\begin{tabular}{|c|c|c|c|c|c|c|}
\hline \multirow[t]{2}{*}{$\begin{array}{l}\text { Smoking } \\
\text { status }\end{array}$} & \multicolumn{2}{|c|}{$\begin{array}{l}\text { Controls } \\
(\boldsymbol{n}=20)\end{array}$} & \multicolumn{2}{|c|}{$\begin{array}{l}\text { Cases } \\
(\boldsymbol{n}=60)\end{array}$} & \multirow[t]{2}{*}{$x^{2}$} & \multirow[t]{2}{*}{${ }^{\mathrm{MC}} p$} \\
\hline & $n$ & $\%$ & $n$ & $\%$ & & \\
\hline Non-smoker & 14 & 70.0 & 14 & 23.3 & $6.989^{*}$ & $0.023^{\circ}$ \\
\hline Smoker & 4 & 20.0 & 38 & 63.3 & & \\
\hline Ex-smoker & 2 & 10.0 & 8 & 13.3 & & \\
\hline
\end{tabular}

$\mathrm{X}^{2}$ : Chi square test, MC: Monte Carlo, $p: p$ value for comparing between the two groups

*Statistically significant at $p \leq 0.05$

common clinical presentations of the population studied (a single subject may have more than one complaint), Table 4 presents their CT findings and Table 5 presents their bronchoscopic findings.

BAL cytology was negative for malignant cells in all controls and in $26.7 \%$ of cases who were later proved to be positive for malignant cells by histopathology of lung biopsy (Table 6).

Table 7 demonstrates the biopsy histopathology results among cases and controls who were negative for malignancy, with $20 \%$ of them showing inflammatory changes.

There was a statistically significant difference between methylated and unmethylated percentage of SHOX2 gene between the two groups, where the percentage of methylated SHOX2 was significantly higher $(p<0.001)$ among lung cancer cases $(21.18 \pm 18.12)$ than controls $(5.62 \pm 1.80)$, as shown in Table 8 .

Background methylation was found among controls; therefore, a receiver operating characteristic (ROC) curve was constructed, as shown in Fig. 1, to calculate the cut-off methylation value that discriminates between cases and controls.

A methylation cut-off value of $7.16 \%$ was calculated, methylation values of more than $7.16 \%$ were

Table 3 Comparison between controls and cases regarding their clinical presentation

\begin{tabular}{|c|c|c|c|c|}
\hline \multirow[t]{2}{*}{ Clinical presentation } & \multicolumn{2}{|c|}{$\begin{array}{l}\text { Controls } \\
(\boldsymbol{n}=20)\end{array}$} & \multicolumn{2}{|c|}{$\begin{array}{l}\text { Cases } \\
(\boldsymbol{n}=60)\end{array}$} \\
\hline & $n$. & $\%$ & $n$. & $\%$ \\
\hline Dyspnea/difficult breathing & 4 & 20.0 & 42 & 70.0 \\
\hline Cough & 6 & 30.0 & 38 & 63.3 \\
\hline Hemoptysis & 6 & 30.0 & 18 & 30.0 \\
\hline Chest pain & 2 & 10.0 & 12 & 20.0 \\
\hline Diabetes mellitus & 2 & 10.0 & 8 & 13.3 \\
\hline Hypertension & 2 & 10.0 & 4 & 6.7 \\
\hline Weight loss & 0 & 0.0 & 2 & 3.3 \\
\hline Alleged foreign body aspiration & 4 & 20.0 & 0 & 0.0 \\
\hline Fungal infection & 2 & 10.0 & 0 & 0.0 \\
\hline
\end{tabular}

NB: a single subject may have more than one complaint
Table 4 Comparison between controls and cases regarding their $C T$ findings

\begin{tabular}{|c|c|c|c|c|c|c|}
\hline \multirow[t]{2}{*}{$C T$ findings } & \multicolumn{2}{|c|}{$\begin{array}{l}\text { Controls } \\
(\boldsymbol{n}=20)\end{array}$} & \multicolumn{2}{|c|}{$\begin{array}{l}\text { Cases } \\
(\boldsymbol{n}=60) \\
\end{array}$} & \multirow[t]{2}{*}{$x^{2}$} & \multirow[t]{2}{*}{$p$} \\
\hline & $n$. & $\%$ & $n$. & $\%$ & & \\
\hline \multicolumn{7}{|l|}{$\mathrm{CT}$} \\
\hline Normal & 4 & 20.0 & 0 & 0.0 & 6.316 & $\mathrm{FE}_{p}=0.058$ \\
\hline Abnormal & 16 & 80.0 & 60 & 100.0 & & \\
\hline \multicolumn{7}{|l|}{ Lesion } \\
\hline Lung mass & 2 & 12.5 & 44 & 73.3 & $18.133^{*}$ & ${ }^{M C} p=0.001$ \\
\hline Lung mass \& nodules & 0 & 0.0 & 8 & 13.3 & & \\
\hline Nodules & 4 & 25 & 6 & 10.0 & & \\
\hline Consolidation & 2 & 12.5 & 2 & 3.3 & & \\
\hline Cavitary lesion & 2 & 12.5 & 0 & 0.0 & & \\
\hline Bronchiectasis & 2 & 12.5 & 0 & 0.0 & & \\
\hline Foreign body & 4 & 25 & 0 & 0.0 & & \\
\hline \multicolumn{7}{|l|}{ Side } \\
\hline Left & 2 & 12.5 & 32 & 53.3 & $6.164^{*}$ & ${ }^{M C} c_{p=0.037^{*}}$ \\
\hline Right & 10 & 62.5 & 26 & 43.3 & & \\
\hline Bilateral & 4 & 25.0 & 2 & 3.3 & & \\
\hline
\end{tabular}

$\mathrm{X}^{2}:$ Chi square test, $M C$ : Monte Carlo, FE: Fisher exact, $p: p$ value for comparing between the two groups

*Statistically significant at $p \leq 0.05$

considered positive. Methylation levels were $\sim 77 \%$ sensitive, $70 \%$ specific with a positive predictive value of $87 \%$ and a negative predictive value of $\sim 54 \%$ in detecting malignancy confirmed by histopathology biopsy (Table 9).

There was no statistical difference when comparing SHOX2 methylation levels between negative BAL cytology cases (16/60) and positive BAL cytology cases $(44 / 60)$. The range of methylation of SHOX2 in cytology negative cases was 7.14-18.5\%, (11.93 $\pm 5.33 \%)$ and a median of $10.11 \%$, whereas $\mathrm{SHOX} 2$ methylation range in

Table 5 Comparison between controls and cases regarding their bronchoscopic findings

\begin{tabular}{|c|c|c|c|c|}
\hline \multirow[t]{2}{*}{ Bronchoscopic findings } & \multicolumn{2}{|c|}{$\begin{array}{l}\text { Controls } \\
(\boldsymbol{n}=20)\end{array}$} & \multicolumn{2}{|c|}{$\begin{array}{l}\text { Cases } \\
(\boldsymbol{n}=60)\end{array}$} \\
\hline & $n$. & $\%$ & $n$. & $\%$ \\
\hline Mass & 2 & 10.0 & 44 & 73.3 \\
\hline Inflammation & 8 & 40.0 & 6 & 10 \\
\hline Nodules & 0 & 0.0 & 4 & 6.7 \\
\hline Mass + bleeds on touch & 0 & 0.0 & 4 & 6.7 \\
\hline Mass + inflammation & 0 & 0.0 & 2 & 3.3 \\
\hline Tracheal web & 2 & 10.0 & 0 & 0.0 \\
\hline Abscess & 2 & 10.0 & 0 & 0.0 \\
\hline Bronchiectasis & 2 & 10.0 & 0 & 0.0 \\
\hline Foreign body & 4 & 20.0 & 0 & 0.0 \\
\hline
\end{tabular}


Table 6 Comparison between controls and cases regarding cytological analysis of BAL

\begin{tabular}{|c|c|c|c|}
\hline $\begin{array}{l}\text { Controls } \\
(\boldsymbol{n}=20)\end{array}$ & $\begin{array}{l}\text { Cases } \\
(\boldsymbol{n}=60)\end{array}$ & $x^{2}$ & ${ }^{\mathrm{FE}} p$ \\
\hline$n$ & 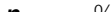 & & \\
\hline
\end{tabular}

\begin{tabular}{lllllll}
\hline Cytology & & & & & & \\
Negative & 20 & 100.0 & 16 & 26.7 & $16.296^{*}$ & $<0.001^{*}$ \\
Positive & 0 & 0.0 & 44 & 73.3 & & \\
\hline$x^{2}$ :Chisquar
\end{tabular}

$\mathrm{x}^{2}$ : Chi square test, FE: Fisher exact, $p: p$ value for comparing between the two groups

*Statistically significant at $p \leq 0.05$

cytology positive cases was $3.9-77.16 \%,(23.96 \pm 19.73 \%)$ with a median of $16.6 .3 \%$.

Significantly different SHOX2 methylation levels were noted among different lung cancer histopathological types $(p=0.03)$, as seen in Table 10. Highest methylation levels were found among squamous cell carcinoma (SCC) cases $(40.61 \pm 1.18 \%)$ with a median of $41.47 \%$. The second highest levels of SHOX2 methylation were found among adenocarcinoma cases (15.01 \pm 6.42\%) with a median of $15.67 \%$. However, CIS cases had the least SHOX2 methylation level $(7.15 \pm 0.01 \%)$ with a median of $7.15 \%$.

\section{Discussion}

To the best of our knowledge, this is the first study conducted on Egyptians comparing SHOX2 gene methylation level between patients having lung cancer and those with benign lung lesions, aiming at investigating its relationship with lung cancer diagnosis. We studied SHOX2 methylation status in 60 patients who proved to have lung cancer on histopathology, in addition to 20 patients with benign lung lesions who served as benign controls. This was achieved using real-time PCR after digestion by restriction enzymes, which were either methylation sensitive (Ms) or methylation dependant (Md).

Table 7 Comparison between controls and cases regarding biopsy histopathology results

\begin{tabular}{|c|c|c|c|c|c|c|}
\hline \multirow[t]{2}{*}{ Biopsy } & \multicolumn{2}{|c|}{$\begin{array}{l}\text { Controls } \\
(\boldsymbol{n}=20)\end{array}$} & \multicolumn{2}{|c|}{$\begin{array}{l}\text { Cases } \\
(\boldsymbol{n}=60)\end{array}$} & \multirow[t]{2}{*}{$x^{2}$} & \multirow[t]{2}{*}{${ }^{\mathrm{MC}} p$} \\
\hline & $n$ & $\%$ & $n$ & $\%$ & & \\
\hline Adenocarcinoma & 0 & 0.0 & 24 & 40.0 & $34.064^{*}$ & $<0.001^{*}$ \\
\hline Squamous cell carcinoma & 0 & 0.0 & 18 & 30.0 & & \\
\hline Anaplastic carcinoma & 0 & 0.0 & 10 & 16.7 & & \\
\hline Carcinoma in situ & 0 & 0.0 & 8 & 13.3 & & \\
\hline Negative & 16 & 80.0 & 0 & 0.0 & & \\
\hline Nonspecific inflammation & 4 & 20.0 & 0 & 0.0 & & \\
\hline
\end{tabular}

$x^{2}$ : Chi square test, MC: Monte Carlo, $p: p$ value for comparing between the two groups

*Statistically significant at $p \leq 0.05$
Table 8 Comparison between controls and cases regarding the percentage of SHOX2 gene methylation

\begin{tabular}{|c|c|c|c|c|}
\hline $\begin{array}{l}\text { Methylation } \\
\text { percentage }\end{array}$ & $\begin{array}{l}\text { Controls } \\
(\boldsymbol{n}=20)\end{array}$ & $\begin{array}{l}\text { Cases } \\
(\boldsymbol{n}=60)\end{array}$ & Test of sig. & $p$ \\
\hline
\end{tabular}

\begin{tabular}{|c|c|c|c|c|}
\hline \multicolumn{5}{|c|}{ Un-methylated SHOX2 (\%) } \\
\hline Min-Max & $92.14-96.48$ & $22.84-96.10$ & $t=4.324^{*}$ & $<0.001^{*}$ \\
\hline Mean \pm S.D. & $94.38 \pm 1.80$ & $78.82 \pm 18.12$ & & \\
\hline Median & 94.92 & 84.34 & & \\
\hline \multicolumn{5}{|c|}{ Methylated SHOX2 (\%) } \\
\hline Min-Max & $3.52-7.86$ & $3.90-77.16$ & $U=23.50^{*}$ & $<0.001^{*}$ \\
\hline Mean \pm S.D. & $5.62 \pm 1.80$ & $21.18 \pm 18.12$ & & \\
\hline Median & 5.08 & 15.67 & & \\
\hline
\end{tabular}

$U$ : Mann Whitney test, $t$ : Student $t$ test, $p$ : $\mathrm{p}$ value for comparing between the two groups

*Statistically significant at $p \leq 0.05$

In our studied patients with lung cancer, smoking was a prevalent risk factor in most of them, as previously reported by Schmidt et al. [17] and Ilse et al. [18], showing that smoking is a common risk factor for lung cancer.

In our study, methylation levels of $\mathrm{SHOX} 2$ gene are expressed as percentages. SHOX2 methylation percentages were found to be significantly higher among cases than controls, $p<0.001$. Different SHOX2 methylation levels are noted in different histopathological lung cancer types showing statistical significance,

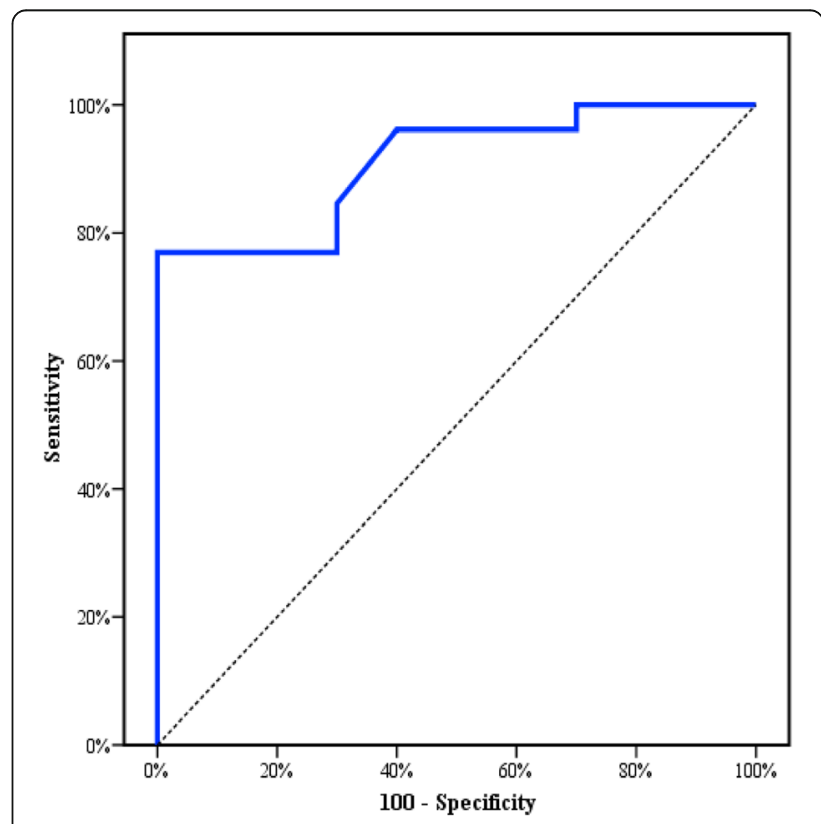

Fig. 1 ROC curve for SHOX2 methylation (\%) to discriminate between lung cancer cases and controls with benign lesions. AUC = 0.91. AUC: area under the curve, $p$ value: probability value, $\mathrm{Cl}$ : confidence interval 
Table 9 Agreement (sensitivity, specificity) for methylated SHOX2 gene percentage to discriminate lung cancer cases from controls having benign lesions

\begin{tabular}{llllll}
\hline & Cut-off & Sensitivity & Specificity & PPV & NPV \\
\hline $\begin{array}{l}\text { SHOX2 methylation } \\
\text { level (\%) }\end{array}$ & $\mathbf{7 . 1 6}$ & $\mathbf{7 6 . 9 2}$ & $\mathbf{7 0 . 0}$ & $\mathbf{8 7 . 0}$ & $\mathbf{5 3 . 8}$ \\
\hline
\end{tabular}

PPV Positive predictive value, NPV Negative predictive value

$p=0.03$. Highest methylation levels are found in SCC cases followed by adenocarcinoma, anaplastic carcinoma (SCLC), and lastly CIS. The cut-off point for positive methylation was calculated to be more than 7.16 by ROC curve.

Dietrich et al. [19], who used Epi proLung BL Reflex kit, established a cut-off for the test to differentiate between positive and negative cases; the cut-off value was $9.5 \%$. Ilse et al. [18] used the same cut-off value, as they used the same kit. Also Schmidt et al. [17] implemented a methylation cut-off value to differentiate between positive and negative results, as background methylation was present in their control samples. Their methodology depended on bisulphite conversion followed by real-time PCR.

Schmidt et al. [17] found that higher methylation levels were noted in both SCLC and SCC than in patients with adenocarcinoma and this indicates a lower sensitivity of $\mathrm{SHOX} 2$ methylation in adenocarcinoma diagnosis. Another reason for the differences in methylation levels is the location of the tumor, as SCC masses are commonly centrally located, which makes BAL of better quality as it is accessible by bronchoscopy, opposite to peripherally located tumors such as adenocarcinoma.

Ilse et al. [18] showed that SCLC was best diagnosed by $\mathrm{SHOX} 2$ methylation percentage, with highest sensitivity $82 \%$, followed by SCC at $81 \%$, adenocarcinoma at $65 \%$, adenocarcinoma NOS at $50 \%$, but there was no significant difference in their study.

In our study, SHOX2 methylation levels showed a sensitivity of $76.92 \%$ and a specificity of $70 \%$ in detecting lung cancer cases. In the study conducted by
Schmidt et al. [17], SHOX2 methylation levels showed a sensitivity of $68 \%$ and a specificity of $95 \%$, while in that conducted by Dietrich et al. [19], SHOX2 methylation levels showed a sensitivity of $78 \%$ and a specificity of $96 \%$, and lastly in the study of Ilse et al. [18], they showed a sensitivity of $64 \%$ and a specificity of $98 \%$.

The difference between our results and those obtained by others may be attributed to the different methodologies used, difference in the number of studied cases, and ethnic differences between the studied populations.

The main limitations of our study are the relatively small sample size and inability to detect other epigenetic changes due to our limited budget. However, among the strong points in this research are the strict exclusion and inclusion criteria adopted for the selection of cases to avoid any confounding factors that could affect the results of our study causing bias.

\section{Conclusions}

In conclusion, the most common histological type of lung cancer among Egyptians enrolled in our study was adenocarcinoma followed by SCC then SCLC and lastly adenocarcinoma in situ. SHOX2 methylation levels could differentiate between lung cancer and benign lung lesions with a significant difference, $p<0.001$. SHOX2 methylation levels differed significantly according to the histological types of tumors, highest in SCC, followed by adenocarcinoma then anaplastic carcinoma and lastly adenocarcinoma in situ. SHOX2 methylation level could not only distinguish between malignant and benign lung lesions but also discriminate between different histological types of lung cancer.

Interestingly, samples that were classified as "cytologically negative" or "inconclusive" due to the absence of malignant cells could be identified as cancer-positive based on their SHOX2 DNA methylation level.

Table 10 Relation between histopathology and SHOX2 methylation \% among the different lung cancer histopathological types $(n=60)$

\begin{tabular}{|c|c|c|c|c|c|c|}
\hline & \multicolumn{4}{|c|}{ Hispathology of lung biopsy $(\boldsymbol{n}=60)$} & \multirow[t]{2}{*}{$H$} & \multirow[t]{2}{*}{$p$} \\
\hline & $\begin{array}{l}\text { Squamous cell carcinoma } \\
(\boldsymbol{n}=18)\end{array}$ & $\begin{array}{l}\text { Adeno-carcinoma } \\
(\boldsymbol{n}=24)\end{array}$ & $\begin{array}{l}\text { Anaplastic carcinoma } \\
(\boldsymbol{n}=10)\end{array}$ & $\begin{array}{l}\text { Adeno-carcinoma in situ } \\
(\boldsymbol{n}=8)\end{array}$ & & \\
\hline \multicolumn{7}{|c|}{ Methylated SHOX2 level (\%) } \\
\hline Min. - Max. & $8.97-77.16$ & $6.57-29.89$ & $3.90-10.48$ & $7.14-7.16$ & $14.199^{*}$ & $0.003^{*}$ \\
\hline Mean \pm SD & $40.61 \pm 1.18$ & $15.01 \pm 6.42$ & $7.85 \pm 3.21$ & $7.15 \pm 0.01$ & & \\
\hline Median & 41.47 & 15.67 & 8.52 & 7.15 & & \\
\hline
\end{tabular}

H: Kruskal Wallis test, $p$ : $p$ value for association between biopsy and percentage of methylated SHOX2

* Statistically significant at $p \leq 0.05$ 


\section{Supplementary information}

Supplementary information accompanies this paper at https://doi.org/10. 1186/s43042-020-00069-1.

Additional file 1: Table S1. PCR cycling protocol.

\section{Abbreviations}

BAL: Broncho-alveolar lavage; CDKN2A/p16: Cyclin-dependent kinase inhibitor 2A/p16; CEA: Carcinoembryonic antigen; CIS: Carcinoma in situ; CpG: Cytosine guanine islands; CT: Computerized tomography; CT: Cycle threshold; CYFRA: Cytokeratin 19 fragment; DNA: Deoxyribonucleic acid; M: Methylated; Md: Methylation-dependent; MDRE: Methylation-dependent restriction enzyme; MGMT: Methyl guanine DNA methyl transferase; Mo: Mock digest; Ms: Methylation-sensitive; Msd: Double digest; MSRE: Methylation-sensitive restriction enzyme; NOS: Not otherwise specified; NSCLC: Non-small cell lung carcinoma; NSE: Neuron-specific enolase; proGRP: Pro-gastrin-releasing peptide; PTPRN2: Protein tyrosine phosphatase receptor type N2; qPCR: Quantitative polymerase chain reaction; ROC: Receiver operating characteristic; ROS: Reactive oxygen species; SCC: Squamous cell carcinoma; SCCA: Squamous cell carcinoma antigen; SCLC: Small cell lung carcinoma; SHOT: SHOX homologous gene on chromosome three; SHOX2: Short stature homeobox 2; SPSS: Statistical package for social sciences; UM: Unmethylated

\section{Acknowledgements}

Not applicable.

\section{Authors' contributions}

MR designed the study. SH performed the pathological investigations. AG selected the patients. DY analyzed and interpreted the data and was a major contributor in writing the manuscript. SM performed the laboratory investigations, data analysis, and drafting the manuscript. The authors certify that each author has participated sufficiently in this research and takes full responsibility for the validity and objectivity of the entire study. All authors have approved the final version of the manuscript. Neither this manuscript nor one with similar content has been published or is being considered for publication in any language.

\section{Funding}

This research did not receive any specific grant from funding agencies in the public, commercial, or not-for-profit sectors and was completely funded by the authors.

\section{Availability of data and materials}

All data generated or analyzed during this study are included in this published article [and its supplementary information file].

\section{Ethics approval and consent to participate}

This study received ethical approval from the Institutional Research Ethics Committee of Alexandria University, Faculty of Medicine. Written informed consents were obtained from all participants before enrolment in the study. The identification information of all subjects was kept confidential and was protected from the public. This work has been carried out in accordance with the Code of Ethics of the World Medical Association (Declaration of Helsinki and its later amendments) for experiments involving humans.

\section{Consent for publication}

The authors certify that each author has participated sufficiently in this research and takes full responsibility for the validity and objectivity of the entire study.

\section{Competing interests}

The authors have nothing to disclose and report no conflict of interest, whether personal or financial.

\section{Author details}

${ }^{1}$ Clinical Pathology Department, Faculty of Medicine, Alexandria University, Khartoom Square, Azarita, Alexandria, Egypt. Pathology Department, Faculty of Medicine, Alexandria University, Alexandria, Egypt. ${ }^{3}$ Pulmonology Department, Faculty of Medicine, Alexandria University, Alexandria, Egypt.
Received: 26 February 2020 Accepted: 27 May 2020

Published online: 01 July 2020

\section{References}

1. Siegel RL, Miller KD, Jemal A (2020) Cancer statistics, 2020. CA Cancer J Clin 70(1):7-30. https://doi.org/10.3322/caac.21590

2. Arrieta O, Lazcano E (2019) Lung cancer: Epidemiology, diagnosis and treatment. Salud Publica Mex 61(3):217-218. https://doi.org/10.21149/10660

3. Zhong L, Goldberg MS, Parent ME, Hanley JA (2000) Exposure to environmental tobacco smoke and the risk of lung cancer: a meta-analysis. Lung Cancer 27:3-18. https://doi.org/10.1016/s0169-5002(99)00093-8

4. Birring SS, Peake MD (2005) Symptoms and the early diagnosis of lung cancer. Thorax. 60:268-269. https://doi.org/10.1136/thx.2004.032698

5. Beadsmoore CJ, Screaton NJ (2003) Classification, staging and prognosis of lung cancer. Eur J Radiol 45:8-17. https://doi.org/10.1016/s0720048x(02)00287-5

6. Latimer KM, Mott TF (2015) Lung cancer: diagnosis, treatment principles, and screening. Am Fam Physician 91:250-256 PMID:25955626

7. Böcking A, Klose KC, Kyll HJ, Hauptmann S (1995) Cytologic versus histologic evaluation of needle biopsy of the lung, hilum and mediastinum, sensitivity, specificity and typing accuracy. Acta Cytol 39:463-471 PMID: 7762333

8. Niho S, Shinkai T (2001) Tumor markers in lung cancer. Gan To Kagaku Ryoho 28:2089-2093 PMID:11791391

9. Dumitrescu RG (2012) Epigenetic markers of early tumor development. Methods Mol Biol 863:3-14. https://doi.org/10.1007/978-1-61779-612-8_1

10. O'Hagan HM, Wang W, Sen S, Destefano Shields C, Lee SS, Zhang YW et al (2011) Oxidative damage targets complexes containing DNA methyltransferases, SIRT1, and polycomb members to promoter CpG Islands. Cancer Cell 20:606-619. https://doi.org/10.1016/j.ccr.2011.09.012

11. Selamat SA, Galler JS, Joshi AD, Fyfe MN, Campan M, Siegmund KD et al (2011) DNA methylation changes in atypical adenomatous hyperplasia, adenocarcinoma in situ, and lung adenocarcinoma. PLoS One 6:e21443. https://doi.org/10.1371/journal.pone.0021443

12. Kim DH, Nelson HH, Wiencke JK, Zheng S, Christiani DC, Wain JC et al (2001) p16 (INK4a) and histology-specific methylation of CpG islands by exposure to tobacco smoke in non-small cell lung cancer. Cancer Res 61: 3419-3424 PMID:11309302

13. Massion PP, Taflan PM, Jamshedur Rahman SM, Yildiz P, Shyr Y, Edgerton ME et al (2003) Significance of p63 amplification and overexpression in lung cancer development and prognosis. Cancer Res 63:7113-7121 PMID: 14612504

14. De Baere E, Speleman F, Van Roy N, De Paepe A, Messiaen L (1998) Assignment of SHOX2 (alias OG12X and SHOT) to human chromosome bands 3q25-- > q26.1 by in situ hybridization. Cytogenet Cell Genet 82:228229. https://doi.org/10.1159/000015108

15. Schneider KU, Dietrich D, Fleischhacker M, Leschber G, Merk J, Schäper F et al (2011) Correlation of SHOX2 gene amplification and DNA methylation in lung cancer tumors. BMC Cancer 11:102. https://doi.org/10.1186/14712407-11-102

16. Binu VS, Mayya SS, Dhar M (2014) Some basic aspects of statistical methods and sample size determination in health science research. Ayu 35:119-123. https://doi.org/10.4103/0974-8520.146202

17. Schmidt B, Liebenberg V, Dietrich D, Schlegel T, Kneip C, Seegebarth A et al (2010) SHOX2 DNA methylation is a biomarker for the diagnosis of lung cancer based on bronchial aspirates. BMC Cancer 10:600. https://doi.org/10. 1186/1471-2407-10-600

18. Ilse P, Biesterfeld S, Pomjanski N, Wrobel C, Schramm M (2014) Analysis of SHOX2 methylation as an aid to cytology in lung cancer diagnosis. Cancer Genomics Proteomics 11:251-258 PMID:25331797

19. Dietrich D, Kneip C, Raji O, Liloglou T, Seegebarth A, Schlegel T et al (2012) Performance evaluation of the DNA methylation biomarker SHOX2 for the aid in diagnosis of lung cancer based on the analysis of bronchial aspirates. Int J Oncol 40:825-832. https://doi.org/10.3892/ijo.2011.1264

\section{Publisher's Note}

Springer Nature remains neutral with regard to jurisdictional claims in published maps and institutional affiliations. 